\title{
Sensitivity evaluation of a single-step PCR assay using Ehrlichia canis $p 28$ gene as a target and its application in diagnosis of canine ehrlichiosis
}

\author{
Avaliação da sensibilidade da PCR em uma etapa com base no gene p28 de Ehrlichia canis \\ e sua aplicação no diagnóstico da erliquiose canina.
}

Andrea Cristina Higa Nakaghi ${ }^{1 *}$; Rosangela Zacarias Machado ${ }^{1}$; Jesus Aparecido Ferro ${ }^{2}$; Marcelo Bahia Labruna ${ }^{3}$;

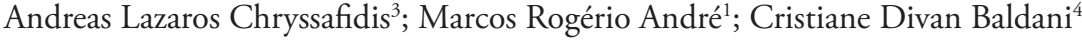

\author{
${ }^{1}$ Laboratório de Imunoparasitologia Veterinária, Departamento de Patologia Veterinária, Faculdade de Ciências Agrárias e Veterinárias, \\ Universidade Estadual Paulista - UNESP \\ ${ }^{2}$ Laboratório de Biologia Molecular, Departamento de Tecnologia, Faculdade de Ciências Agrárias e Veterinárias, \\ Universidade Estadual Paulista - UNESP \\ ${ }^{3}$ Departamento de Medicina Veterinária Preventiva e Saúde Animal, Faculdade de Medicina Veterinária e Zootecnia, \\ Universidade de São Paulo - USP \\ ${ }^{4}$ Escola de Medicina Veterinária e Zootecnia, Campus de Araguaína, Universidade Federal do Tocantins - UFT
}

Recebido em 19 de Outubro de 2009

Aceito em 26 de Abril de 2010

\begin{abstract}
The aim of this study was to optimize a PCR assay that amplifies an $843 \mathrm{pb}$ fragment from the $p 28$ gene of Ehrlichia canis and compare it with two other PCR methods used to amplify portions of the 16S rRNA and dsb genes of Ehrlichia. Blood samples were collected from dogs suspected of having a positive diagnosis for canine ehrlichiosis. Amplification of the $p 28$ gene by PCR produced an 843 -bp fragment and this assay could detect DNA from one gene copy among 1 billion cells. All positive samples detected by the $p 28$-based PCR were also positive by the $16 \mathrm{~S}$ rRNA nested-PCR and also by the $d s b$-based PCR. Among the $p 28$-based PCR negative samples, $55.3 \%$ were co-negatives, but $27.6 \%$ were positive in $16 \mathrm{~S}$ rRNA and $d s b$ based PCR assays. The $p 28$-based PCR seems to be a useful test for the molecular detection of $E$. canis, however improvements in this PCR sensitivity are desired, so that it can become an important alternative in the diagnosis of canine ehrlichiosis.
\end{abstract}

Keywords: Ehrlichia canis, PCR, p28, dsb gene, $16 \mathrm{~S}$ rRNA gene.

\section{Resumo}

O objetivo deste estudo foi aperfeiçoar um ensaio de PCR que amplificasse um fragmento de 843 pares de bases do gene $p 28$ da Ehrlichia canis e compará-lo com outros dois métodos de PCR utilizados para amplificar partes do gene $16 \mathrm{~S}$ rRNA e $d s b$ do gênero Ehrlichia. Amostras sanguíneas foram colhidas de cáes com diagnóstico clínico de erliquiose. A amplificação do gene $p 28$ pela PCR produziu um fragmento de $843 \mathrm{pb}$ e esse ensaio permitiu a detecçáo do DNA de um parasita dentre 1 bilháo de células. Todas as amostras positivas detectadas pela PCR baseada no gene p28 foram também positivas pela nested PCR para detecçáo do gene $16 \mathrm{~S}$ rRNA e também pela PCR $d s b$. Dentre as amostras negativas para a PCR $p 28,55,3 \%$ foram co-negativas, mas $27,6 \%$ foram positivas pela PCR baseada nos genes $16 \mathrm{~S}$ rRNA e $d s b$. A PCR $p 28$ parece ser um teste útil para deteç̧áo molecular de E. canis, entretanto otimizaçóes na sensibilidade nesta PCR são necessárias, para que esta técnica se torne uma importante alternativa no diagnóstico da erliquiose canina.

Palavras-chave: Ehrichia canis, PCR, $p 28$, gene $d s b$, gene 16S rRNA.

\footnotetext{
*Corresponding author: Andrea Cristina Higa Nakaghi

Laboratório de Imunoparasitologia Veterinária,

Departamento de Patologia Veterinária, Faculdade de Ciências Agrárias e Veterinárias,

Universidade Estadual Paulista - UNESP, Rod. Paulo Donato Castellane, km 5.

CEP 14884-900 Jaboticabal - SP, Brasil;

e-mail: andreahn@gmail.com.
} 


\section{Introduction}

Canine monocitic ehrlichiosis is an important tick-borne disease caused by the obligate intracellular bacterium Ehrlichia canis, which has worldwide distribution especially in tropical and subtropical areas. In Brazil, this parasite was first described in 1973 (COSTA, 1973), and is the most common species among the Ehrlichia genus (DAGNONE et al., 2003; MACHADO, 2004; LABRUNA et al., 2007; NAKAGHI et al., 2008).

Definitive diagnosis of canine ehrlichiosis is based on hematological, biochemical, and serologic findings. Direct detection of the intracytoplasmatic E. canis morulae in blood smears is a rapid and low cost diagnosis method, however, according to Cowell et al. (1988), the proportion of infected cells in a serological positive animal may be less than $1 \%$ and the absence of the E. canis morulae do not exclude positive diagnostic (EWING, 1969). The immunofluorescence assay test (IFAT) and Dot-ELISA are the serology tests usually used to detect antibodies anti-E. canis in sera of suspected dogs. Despite of serology is a sensitive test, it cannot distinguish current infection from either exposure without establishment of infection or previous infection (IQBAL; CHAICHANASIRIWITHAYA; RIKIHISA, 1994), and titers might remain high after infection for an additional period of more than 11 months (HARRUS et al., 1998). Because of the disadvantages of these methods, PCR has been used as a complement in the diagnosis of canine ehrlichiosis, due to its high sensitivity and specificity for detection of low levels of $E$. canis DNA (Iqbal; Rikihisa, 1994). This technique can be used to confirm active infection, and establish failure or success of treatment of ehrlichial infections (IQBAL; CHAICHANASIRIWITHAYA; RIKIHISA, 1994).

A single-step PCR targeting E. canis $16 \mathrm{~S}$ rRNA gene in blood and tissues of experimentally infected dogs was often not sensitive enough to detect a few organisms, therefore, nested-PCR test was performed to increase sensitivity and specificity in the detection of E. canis in blood specimens (WEN et al., 1997; HARRUS et al., 1998; NAKAGHI et al., 2008; SEAMAN et al., 2004). However, nested-PCR has the disadvantage of a high risk for sample cross-contamination and detection of false positives (KWOK; HIGUCHI, 1989; LABRUNA et al., 2007). Single-step PCR assays offer several advantages over nested PCR, including reduced labor, reduced cost and cross-contamination, and adaptability to quantitative technique such as competitive or real-time PCR (WAGNER et al., 2004).

Many PCR methods for the detection of infections by Ehrlichia species have been described (CHANG; PAN, 1996; ENGVALL et al., 1996; STICH et al., 2002; DUMLER, 2003). Primers used to detect ehrlichial organisms may be generic or speciesspecific. Generic primers detect many of the organisms in related genus groups, while specific primers designed to amplify highly variable portions of the genome can be chosen to identify only a particular species of organism (BREITSCHWERDT et al., 1998). The PCR protocol widely employed to detect $E$. canis is the $16 \mathrm{~S}$ rRNA nested-PCR, but limited sequence variation of this gene between related bacteria results in unspecific amplification (SUMNER et al., 1997; WHITLOCK et al., 2000). A highly sensitive and specific real-time PCR was used, targeting the Ehrlichia disulfide bond formation protein $(d s b)$ gene, which was identical to the corresponding sequence of the North American isolate (LABRUNA et al., 2007). This $d s b$ PCR protocol has been successfully employed in conventional PCR analyzed in agarose gel (AGUIAR et al., 2007).

Although ehrlichiosis pathogenesis is poorly understood, some studies show that multigene families described in members of the genus Ehrlichia may be involved in the evasion of host immune system by the variation of major surface antigen expression (McBRIDE; YU; WALKER, 2000). The $28 \mathrm{kDa}$ immunodominant outer membrane protein of $E$. canis encoded by a multigene family ( $p 28$ gene) has been recently reported and this gene may be conserved in North America. It is likely that the P28 protein of $E$. canis has a similar location and function to that of the P28 of E. chaffeensis. There are evidences that the E. canis P28 protein may be a reliable serodiagnostic antigen (McBRIDE; YU; WALKER, 1999).

The purpose of this study was to develop a PCR assay based on amplification of the $E$. canis $p 28$ gene and to compare this technique with two PCR methods used to amplify the 16S rRNA and $d s b$ genes of Ehrlichia.

\section{Material and Methods}

\section{Blood samples and DNA extraction}

Ninety-six blood samples were collected from dogs suspected of having a positive diagnosis for canine ehrlichiosis by the attending clinician at the Veterinary Teaching Hospital, UNESP, Jaboticabal, SP. These samples were previously tested by nested-PCR to detect E. canis $16 \mathrm{~S}$ rRNA gene. Positive control blood was collected from an $E$. canis experimentally-infected dog used in previous studies in the Immunoparasitology Laboratory - UNESP/ Jaboticabal (CASTRO et al., 2004) and negative control was collected from the same dog before the infection. DNA was extracted by using the QIAamp Blood Kit according to the manufacturer's recommendations (QIAGEN, Inc.).

\section{Selection of PCR primers}

PCR primers were designed based on a previously sequenced conserved region to amplify a partial locus of the $p 28$ gene (McBRIDE; YU; WALKER, 1999) (GenBank accession number EF014897). Forward primer (ECp28-F) and reverse primer (ECp28-R) could amplify the 843-bp open reading frame. Primers used in nested-PCR to amplify a portion of the 16S rRNA Ehrlichia genus were ECC and ECB, and HE3 and ECAN primers were used to amplify the E. canis $16 \mathrm{~S}$ rRNA gene (MURPHY et al., 1998; MACIEIRA et al, 2005; NAKAGHI et al., 2008). Primers used in another PCR protocol to amplify a 409-bp fragment of the disulfide bond formation protein gene ( $d s b)$ of Ehrlichia spp. were designated as Dsb-330 and Dsb-728 (LABRUNA et al., 2007) (Table 1). 
Table 1. Primers used in PCR assays to amplify Ehrlichia genes.

\begin{tabular}{|c|c|c|}
\hline Gene & $\begin{array}{c}\text { Primers } \\
\text { (f) forward (r) reverse }\end{array}$ & $\begin{array}{c}\text { Sequence } \\
5,-3\end{array}$ \\
\hline$p^{28}$ & ECp28-R (r) & 5' TTA GAA GTT AAA TCT TCC TCC 3’ \\
\hline \multirow{2}{*}{ 16S rRNA } & $\operatorname{ECC}(f)$ & 5'- GAACGAACGCTGGCGGCAAGC -3' \\
\hline & $\mathrm{ECB}(\mathrm{r})$ & 5’- CGTATTACCGCGGCTGCTGGCA -3' \\
\hline \multirow{2}{*}{$d s b$} & Dsb-330 (f) & 5'- GATGATGTCTGAAGATATGAAACAAAT -3’ \\
\hline & Dsb-728 (r) & 5'-CTGCTCGTCTATTTTACTTCTTAAAGT -3' \\
\hline
\end{tabular}

\section{PCR assays}

Amplification of a portion of the gene $p 28$ consisted of a $50 \mu \mathrm{L}$ reaction containing $5 \mu \mathrm{L}$ of template DNA in $5 \mu \mathrm{L}$ PCR buffer $10 \times(100 \mathrm{mM}$ Tris-HCl, pH 9.0, $500 \mathrm{mM} \mathrm{KCl}), 0.2 \mathrm{mM}$ each dNTP, $2.5 \mathrm{mM} \mathrm{MgCl}_{2}, 0.5 \mathrm{pmol}$ each primer, $1.25 \mathrm{U}$ of Taq DNA polymerase. The amplification profile consisted of $95^{\circ} \mathrm{C}$ for 5 minutes, 30 cycles at $95^{\circ} \mathrm{C}$ for 30 seconds, annealing temperature gradient ranging from 40 to $60{ }^{\circ} \mathrm{C}$ for 1 minute and $72{ }^{\circ} \mathrm{C}$ for 2 minutes, followed by a final extension at $72{ }^{\circ} \mathrm{C}$ for 5 minutes. The PCR results were visualized in a $1.3 \%$ agarose gel containing ethidium bromide. The $16 \mathrm{~S}$ rRNA gene fragment amplification was performed as previously described (NAKAGHI et al., 2008). The $d s b$ gene fragment was amplified as previously described (AGUIAR et al. 2007). The sensitivity of the $p 28$-based PCR was analyzed from an E. canis-infected DH82 monolayer 100\% infected diluted 10 -fold in distilled water.

\section{Results}

\section{Optimization of the p28-based PCR.}

Detection of $E$. canis $p 28$ gene by PCR was optimized with genomic DNA extracted from the blood sample of an infected dog. Reactions were submitted to an annealing temperature gradient ranging from 40 to $60{ }^{\circ} \mathrm{C}$. Amplification could be observed up to $55^{\circ} \mathrm{C}$ and the best amplification was observed at $52{ }^{\circ} \mathrm{C}$, then this was the annealing temperature chosen for the $p 28$-based PCR. Sensitivity was analyzed from an $E$. canis culture with $100 \%$ rickettsemia. This PCR assay was able to amplify target template diluted as much as $1 \times 10^{-7} \%$ (Figure 1 ), or 1 parasite among $10^{9}$ cells.

\section{PCR assays to amplify Ehrlichia genes.}

A total of 96 DNA samples were tested by $p 28$-based PCR, nested PCR to amplify the $16 \mathrm{~S}$ rRNA gene, and by PCR to detect $d s b$ gene. Amplification of the $p 28$ gene was demonstrated by an 843 -bp fragment and it was visualized in 49 samples (51\%). The

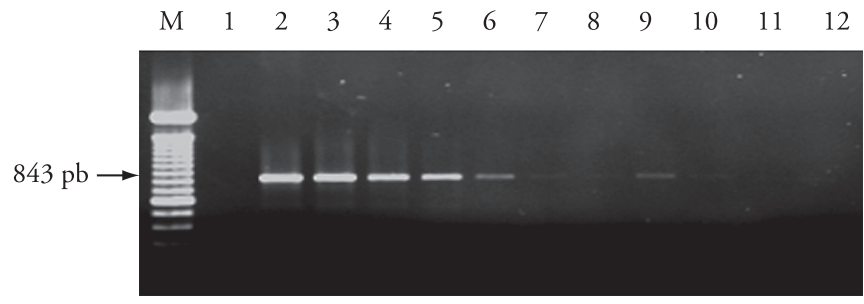

Figure 1. Sensitivity of the $p 28$-based PCR assay analyzed from an E. canis-infected DH82 monolayer 100\% infected diluted 10-fold in distilled water. $\mathrm{M}$, molecular standard size; lane 1, negative control; lanes 2 to 12 , represent assays of the same template dilutions of $1 \times 10^{0}, 1 \times 10^{-1}, 1 \times 10^{-2}, 1 \times 10^{-3}, 1 \times 10^{-4}, 1 \times 10^{-5}, 1 \times 10^{-6}, 1 \times 10^{-7}$, $1 \times 10^{-8}, 1 \times 10^{-9}, 1 \times 10^{-10}$, respectively.

other 47 samples (49\%) were negative in this PCR. Nested-PCR positive samples were demonstrated by the amplification of a $398 \mathrm{bp}$ fragment of the $16 \mathrm{~S}$ rRNA gene of E. canis. This PCR system was able to detect 66 positive samples $(68.7 \%)$, and 30 samples $(31.3 \%)$ were negative. Ehrlichia dsb gene was detected by PCR in 66 samples $(68.7 \%)$ and it was not observed in 30 samples $(31.3 \%)$. All positive samples by $p 28$-based PCR were also detected in $16 \mathrm{~S}$ rRNA and $d s b$ gene. On the other hand, among the PCR negative samples (47), only 26 (55.3\%) were simultaneously negative by nested PCR and the $d s b$-based PCR, and 13 negative samples (27.6\%) were positive for these later two tests (Table 2).

\section{Discussion and Conclusions}

Canine monocitic ehrlichiosis is an important widely spread disease in Brazil, caused by Ehrlichia canis (DAGNONE et al, 2003; MACHADO, 2004; NAKAGHI et al, 2008). Ehrlichial infections can mimic several other diseases and nonspecific clinical signs make the diagnosis difficult (COHN, 2003). The diagnosis of ehrlichiosis can be achieved by a combination of clinical and hematological presentation, serology and molecular biology tests (NAKAGHI et al, 2008). 
Table 2. Comparison between results obtained by $p 28$-based PCR, nested PCR for the amplification of 165 rRNA gene, and PCR for the detection of $d s b$ gene in 96 canine DNA samples.

\begin{tabular}{|c|c|c|c|c|c|c|}
\hline \multicolumn{3}{|c|}{$\begin{array}{c}p 28 \text { positives } \\
\mathrm{n}=49\end{array}$} & \multicolumn{3}{|c|}{$\begin{array}{c}p 28 \text { negatives } \\
\mathrm{n}=47\end{array}$} & \multirow[t]{3}{*}{$\begin{array}{c}\text { Total } \\
\mathrm{n}=96\end{array}$} \\
\hline \multirow{2}{*}{ 16S rRNA } & \multicolumn{2}{|c|}{$d s b$} & \multirow{2}{*}{ 16S rRNA } & \multicolumn{2}{|c|}{$d s b$} & \\
\hline & Positive & Negative & & Positive & Negative & \\
\hline Positive & 49 & 0 & Positive & 13 & 4 & 17 \\
\hline Negative & 0 & 0 & Negative & 4 & 26 & 30 \\
\hline Total & 49 & 0 & Total & 17 & 30 & 47 \\
\hline
\end{tabular}

DNA amplification by PCR has improved the sensitivity and specificity of the diagnosis of ehrlichiosis (IQBAL; CHAICHANASIRIWITHAYA; RIKIHISA, 1994). There are many reports about PCR techniques for the detection of E. canis DNA, but only a few studies compared their sensitivity and specificity. In this study the optimization of PCR to detect a partial locus of the E. canis $p 28$ gene was developed and this assay could amplify an $843 \mathrm{bp}$ fragment, in agreement with the sequence found in GenBank (EF014897).

To determine the sensitivity and specificity of the PCR to detect gene $p 28$, a comparison with $16 \mathrm{~S}$ rRNA-based nested PCR and $d s b$-based PCR was performed. The $p 28$ PCR system exhibited less sensitivity than the other PCR assays. The nested PCR sensitivity was previously evaluated and it could detect $E$. canis DNA to an equivalent rickettsemia of one infected monocyte in $10^{36}$ cells (NAKAGHI et al., 2008). The dsb primers used to amplify the Ehrlichia spp $d s b$ gene was previously evaluated in an real-time assay, in which it was able to detect as few as 10 copies of $E$. canis (LABRUNA et al., 2007). The $p 28$-based PCR was able to detect 1 parasite among $10^{9}$ cells. Probably, the lower sensitivity found in this study could be associated to the large size of the $p 28$ amplicon. Single-step $p 28$ based PCR assay used to detect $E$. chaffeensis was 1000 -fold more sensitive than nested 16S rDNA-based PCR assay, when PCR amplified a 277 bp fragment. PCR assays with species-specific sequences, rather than highly conserved bacterial sequences are likely to provide sensitive and specific tests (WAGNER et al., 2004). Development of a $p 30$-based PCR assay with primer sequences located within a specific region of 135 bp or less increased sensitivity and specificity (STICH et al., 2002).

The nested PCR assay to detect 16S rRNA gene is the most common molecular method used to diagnose ehrlichiosis (BULLA et al., 2004; MACIEIRA et al., 2005; SANTOS et al., 2007; NAKAGHI et al., 2008). However, this method can result in unspecific amplification, due to the highly conserved 16S rRNA gene among strains of species of Ehrlichia, and is at higher risk of DNA cross-contamination (LABRUNA et al., 2007). Besides that, single-step PCR offers some advantages over nested PCR, including reduced labor, cost and timing, and lower risk of DNA cross-contamination (KWOK; HIGUCHI, 1989; WAGNER et al., 2004). Real-time PCR is usually a very sensitive PCR system because primers are designed under highly developed softwares that indicate the most efficient combination of oligos. Once these oligos are chosen and tested their efficiency, they can be applied with the same success to routine PCR assays that are interpreted in agarose gel runs (AGUIAR et al., 2007). In addition, the $d s b$ gene is a conserved gene among Ehrlichia species. Nevertheless, this system detects the presence of the Ehrlichia genus but digestion with restriction enzymes or DNA sequencing is necessary to differentiate the ehrlichial species (LABRUNA et al., 2007). Therefore, a single-step PCR assay that amplifies the $p 28$ gene seems to be the most specific method to detect Ehrlichia canis DNA.

Development of PCR assays can provide sensitive and/or specific tests to be used in the diagnosis of experimental or natural infections. The $p 28$-based PCR seems to be a useful test for the molecular detection of $E$. canis, but studies with primers targeting a specific region inside gene $p 28$ may improve the sensitivity of this method, so it can be an important alternative in the diagnosis of canine ehrlichiosis.

\section{References}

AGUIAR, D. M. et al. Prevalence of Ehrlichia canis (Rickettsiales: Anaplasmataceae) in dogs and Rhipicephalus sanguineus (Acari: Ixodidae) ticks from Brazil. Journal of medical entomology, v. 44, n. 1, p. 126-132, 2007.

BREITSCHWERDT, E. B.; HEGARTY, B. C.; HANCOCK, S. I. Doxycycline hyclate treatment of experimental canine ehrlichiosis followed by challenge inoculation with two Ehrlichia canis strains. Antimicrobial Agents Chemother, v. 42, n. 2, p. 362-368, 1998.

BULLA, C. et al. The relationship between the degree of thrombocytopenia and infection with Ehrlichia canis in an endemic area. Veterinary Research, v.35, n. 1, p. 141-146, 2004.

CASTRO, M. B. et al. Experimental acute canine monocytic ehrlichiosis: clinicopathological and immunopathological findings. Veterinary Parasitology, v. 119, n. 1, p. 73-86, 2004.

CHANG, W. L; PAN, M. J. Specific amplification of Ehrlichia platys dna from blood specimens by two-step PCR. Journal Clinical Microbiology, v. 34, n. 12, p. 3142-3146, 1996.

COHN, L. A. Ehrlichiosis and related infections. Veterinary Clinics Small Animals, v. 33, n. 4, p. 863-884, 2003.

COSTA, J. O. et al. Ehrlichia canis infection in dog in Belo Horizonte: Brazil. Arquivos da Escola de Veterinária da Universidade Federal de Minas Gerais, v. 25, n. 2, p. 199-200, 1973.

DAGNONE, A. S. et al. Ehrlichiosis in anemic, thrombocytopenic, or tick-infested dogs from a hospital population in South Brazil. Veterinary Parasitology, v. 117, n. 4, p. 285-290, 2003. 
DUMLER, J. S. Molecular methods for ehrlichiosis and Lyme disease. Clinics in Laboratoty Medicine, v. 23, n. 4, p. 867-884, 2003.

ENGVALL, E. O. et al. A $16 S$ rRNA-based PCR assay for detection and identification of granulocytic Ehrlichia species in dogs, horses, and cattle. Journal Clinical Microbiology, v. 34, n. 9, p. 2170-2174, 1996.

HARRUS, S. et al. Amplification of ehrlichial DNA from dogs 34 months after infection with Ehrlichia canis. Journal Clinical Microbiology, v. 36, n. 1, p. 73-76, 1998.

IQBAL, Z.; CHAICHANASIRIWITHAYA, W.; RIKIHISA, Y. Comparison of PCR with other tests for early diagnosis of canine ehrlichiosis. Journal Clinical Microbiology, v. 32, n. 7, p. 1658-1662, 1994.

IQBAL, Z.; RIKIHISA, Y. Application of the polymerase chain reaction for the detection of Ehrlichia canis in tissues of dogs. Veterinary Microbiology, v. 42, n. 4, p. 281-287, 1994.

KWOK, S.; HIGUCHI, R. Avoiding false positives with PCR. Nature, v. 339, n. 6221 p. $237-238,1989$.

LABRUNA, M. B. et al. A preliminary investigation of Ehrlichia species in ticks, humans, dogs, and capybaras from Brazil. Veterinary Parasitology, v. 143, n. 2, p. 189-195, 2007.

MACHADO, R. Z. Erliquiose canina. Revista Brasileira de Parasitologia Veterinária, v. 13, supl. 1, p. 53-57, 2004.

MACIEIRA, D. B. et al. Prevalence of Ehrlichia canis infection in thrombocytopenic dogs from Rio de Janeiro, Brazil. Veterinary Clinical Pathology, v. 34, n. 1, p. 44-48, 2005.

McBRIDE, J. W.; YU, X. J.; WALKER, D. H. A conserved, transcriptionally active p28 multigene locus of Ehrlichia canis. Gene, v. 254, n. 1-2, p. 254-252, 2000.

McBRIDE, J. W.; YU, X. J.; WALKER, D. H. Molecular cloning of the gene for a conserved major immunoreactive 28-kilodalton of Ehrlichia canis: a potential serodiagnostic antigen. Clinical and Diagnostic Laboratory Immunology, v. 6, n. 3, p. 392-399, 1999.
MURPHY, G. L. et al. A molecular and serologic survey of Ehrlichia canis, E. chaffeensis and E. ewingii in dogs and ticks from Oklahoma. Veterinary Parasitology, v. 79, n. 4, p. 325-339, 1998.

NAKAGHI, A. C. H. et al. Canine ehrlichiosis: clinical, hematological, serological and molecular aspects. Ciência Rural, v. 38, n. 3, p. 766-770, 2008.

SANTOS, F. et al. Molecular evaluation of the incidence of Ehrlichia canis, Anaplasma platys and Babesia spp. in dogs from Ribeirão Preto, Brazil. Veterinary Journal, v. 179, n. 1, p. 145-148, 2009.

SEAMAN, R. L. et al. Comparison of results for serologic testing a polymerase chain reaction assay to determine the prevalence of stray dogs in eastern Tennessee seropositive to Ehrlichia canis. American Journal Veterinary Research, v. 65, n. 9, p. 1200-1203, 2004.

STICH, R. W. et al. Detection of Ehrlichia canis in canine carrier blood and in individual experimentally infected ticks with a p30-based PCR assay. Journal Clinical Microbiology, v. 40, n. 2, p. 540-546, 2002.

SUMNER, J. W.; NICHOLSON, W. L.; MASSUNG, R. F. PCR amplification and comparison of nucleotide sequences from groESL shock operon of Ehrlichia species. Journal Clinical Microbiology, v. 35, n. 8, p. 2087-2092, 1997.

WAGNER, E. T. Development of a p28-based PCR assay for Ehrlichia chaffeensis. Molecular and Cellular Probes, v. 18, n. 2, p. 111-116, 2004.

WEN, B. et al. Comparison of nested PCR with immunofluorescent-antibody assay for detection of Ehrlichia canis infection in dogs treated with doxycycline. Journal Clinical Microbiology, v. 35, n. 7, p. 1852-1855, 1997.

WHITLOCK, J. E. Prevalence of Ehrlichia chaffeensis (Rickettsiales: Rickettsiaceae) in Amblyomma americanum (Acari: Ixodidae) from the Georgia coast and barrier Islands. Journal Medicine Entomology, v. 37, n. 2, p. 276-280, 2000. 